\title{
Chevaadu - A New Registered Sheep Breed of Tamil Nadu, India
}

\author{
T. Ravimurugan* \\ Veterinary University Training and Research Centre, Tamil Nadu Veterinary and Animal \\ Sciences University (TANUVAS), Nagercoil - 629 601, Tamil Nadu, India \\ *Corresponding author
}

\begin{tabular}{|l|l|}
\hline \multicolumn{1}{l|}{ A B S T R A C T } \\
\cline { 2 - 2 } $\begin{array}{l}\text { Keywords } \\
\text { Tamil Nadu. }\end{array}$ & $\begin{array}{l}\text { The population of Chevaadu sheep is considered as cultural identity of } \\
\text { people of southern Tamil Nadu. Mamman Kida and Kida Vettu are the two } \\
\text { important cultural events / festivals of southern Tamil Nadu; they prefer } \\
\text { only Chevaadu rams for these festivals. Considering the significant role of } \\
\text { this breed of sheep being played in the rural livelihood of communities } \\
\text { rearing them for meat, Tamil Nadu Veterinary and Animal Sciences }\end{array}$ \\
\hline $\begin{array}{l}\text { Article Info } \\
\text { 19 July 2017 } \\
\text { Available Online: } \\
\text { 10 September 2017 }\end{array}$ & $\begin{array}{l}\text { University (TANUVAS) contributed a significant role for elevation of } \\
\text { Chevaadu to a level of a registered breed. }\end{array}$ \\
\hline \hline
\end{tabular}

\section{Introduction}

Tirunelveli district, apparently a dry region, has contributed unique livestock species, such as Kanni aadu and Pallai aadu goat, Kanni and Chippiparai dog, Kilakarsal and Chevaadu sheep, not only for Tamil Nadu but also to the nation. Rich livestock diversity in the district attributed the hard work of pastoral communities who have been conserving and protecting such germplasm suited to the local ecosystem. The most interesting of such germplasm is Chevaadu sheep, probably the only sheep breed of Tamil Nadu that have single coat colour (Ravimurugan and Panneerselvam, 2013). Chevaadu is considered as unique, culturally important breed as it survives on dry land as well as coastal ecosystems. Although, both the males and female of this breed are used for meat purpose the males are very specially utilised to serve the religious purposes of the local inhabitants. This paper deals the biography of Chevaadu sheep and practices of management adopted by the farmers in the breeding tract.

\section{Materials and Methods}

The survey on Chevaadu sheep was carried out between October 2010 and December 2012 to document the habitat, morphology and production and reproduction performances of the breed and the husbandry practices adopted by the farmers in the breeding tract. The habitat and distribution of Chevaadu was ascertained by visiting 22 villages and observing 347 flocks and three weekly markets in Tirunelveli and Tuticorin districts of Tamil Nadu. The breed characters 
of Chevaadu were studied as per the sheep descriptors of the Food and Agriculture Organization (FAO, 1986) and the guidelines given by the National Bureau of Animal Genetic Resources, Karnal, Haryana.

Data on reproduction traits of rams and ewes were recorded by observation and information provided by the farmers through questionnaire. Information on housing pattern, feeding and breeding practices, lamb care, marketing of animals and other husbandry practices were collected through questionnaire. The socio-economic status of Chevaadu sheep farmers was studied from 82 farmers and information on family size, land holding, flock size and income were collected. The data collected were scrutinized, edited and collated. The basic statistics consisting of mean, standard deviation, standard error (SE), coefficient of variation (CV \%) were computed as per Snedecor and Cochran (1989).

\section{Results and Discussion}

\section{Origin, habitat and distribution}

Hindus in the area preferred only brown coat colour ram especially for making offerings to the local Goddess. This paved the way for development of brown coat sheep by the farmers from the existing sheep breeds. It is likely that the breed might have been originated from Kilakarsal (a breed predominantly $\tan$ ) due to the contiguity of the breeding tracts. Katchakatty breed is also likely to be one of the progenitors of the breed for similar reason. Both the breeds are considered to have contributed to the evolution of Chevaadu sheep.

Ganesakale and Rathnasabapathy (1973) and Acharya (1982) have described the distinct geographical distribution, morphology and morphometric characteristics of the eight recognized breeds of Tamil Nadu viz. Madras
Red, Tiruchy Black, Coimbatore, Mecheri, Nilagiri, Ramnad White, Vembur and Kilakarsal. However, the Chevaadu sheep finds no mention in the list of breed made by the above authors. But on personal interaction during the survey on Chevaadu sheep, it was revealed by the traditional sheep breeders of Tirunelveli district that Chevaadu sheep has found a pride of place in their flocks since long back. The wizened flock men mentioned that they have been rearing Chevaadu sheep generations together and its legacy was known to them for the past 50-75 years.

Mainly Konar and Pallar communities in Alangulam, Tirunelveli, Sankarankovil and Nanguneri taluka raise Chevaadu sheep. People in Kuruvikulam, Pappakudi, Melaneelithanallur, Manur, and Nanguneri as well as Ottapidaram Panchayat Union areas of Tuticorin District are keeping such unique sheep breed by maintaining sole extensive system.

Table 1 indicates the distribution of sheep breeders in different categories according to flock size. The survey found that majority of breeders $(24.85 \%)$ have very large sized flocks of $>100$ sheep followed by $24.70 \%$ large sized flocks of 76-100, whereas $28.03 \%$ of the breeders have less than 50 sheep with them. It is also noted that 56 out of 251 sheep breeders have medium flock (51-75).

\section{Morphology}

The animals are small to medium in size with compact body conformation. The coat colour is generally brown. The intensity of coat colour varied from light brown to tan. In general, dorsal part of the body is light brown in colour and in the ventral part (from the jaw to inguinal region), The brown colour is lighter than in the dorsal part. These animals are called as "Arichevaadu". Rams of such breed description are selected for breeding in most of the flocks. The dark brown/tan coat 
colour sheep is named as "Karunchevaadu" and surprisingly they appeared similar to Madras Red breed of sheep. The color and other morphological characters of Chevaadu sheep were distinct from other southern Tamil Nadu sheep breeds, viz., Kilakarsal, Katchakatty and Pattanam (Kumarasamy et al., 2009; Ravimurugan et al., 2012). The Chevaadu sheep was also distinct from other south Indian breeds, viz., Bellary, Deccani, Hassan, Mandya and Nellore (Bhatia and Arora, 2005).

\section{Reproduction}

The age at first breeding for male sheep was nine months, whereas it was 12 months in females. The oestrous cycle varying from $21-$ 22 days with a oestrous duration of 35 hours.
The age at first lambing was about 18 months. The lambing interval and gestation length were 258 and 148 days respectively. Chevaadu sheep lambed thrice in two years. Litter size was single with rare case of twinning.

Generally, a ewe produce six lambs during its lifetime, but well cared ewes can produce seven lambs. Lambing rate in majority of the flocks was 72 per cent in main season and 28 per cent in off season. The overall lambing percentage was 96. Reproductive disorders were not much common in Chevaadu sheep.

The lambing percentage observed in Chevaadu was higher than the other hair sheep of Tamil Nadu viz. Vembur (Chandran, 1998), Ramnad White (Mahendran, 2009).

Table.1 Distribution of Chevaadu sheep farmers

\begin{tabular}{|c|c|c|}
\hline Flock size & No. of Sheep Breeders & Percentage \\
\hline Marginal (<25 sheep) & 29 & 11.53 \\
\hline Small (26 to 50) & 41 & 16.50 \\
\hline Medium (51 to 75) & 56 & 22.42 \\
\hline Large (76 to 100$)$ & 62 & 24.70 \\
\hline Very large (>100) & 63 & 24.85 \\
\hline Total & $\mathbf{2 5 1}$ & $\mathbf{1 0 0}$ \\
\hline
\end{tabular}

Fig.1 Koodu

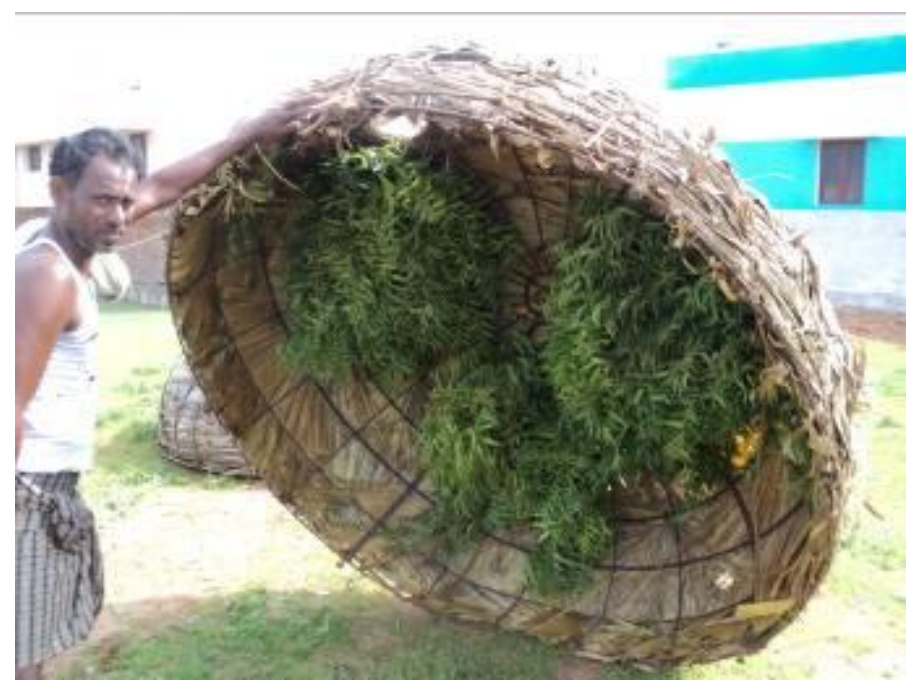


Fig.2 Water source

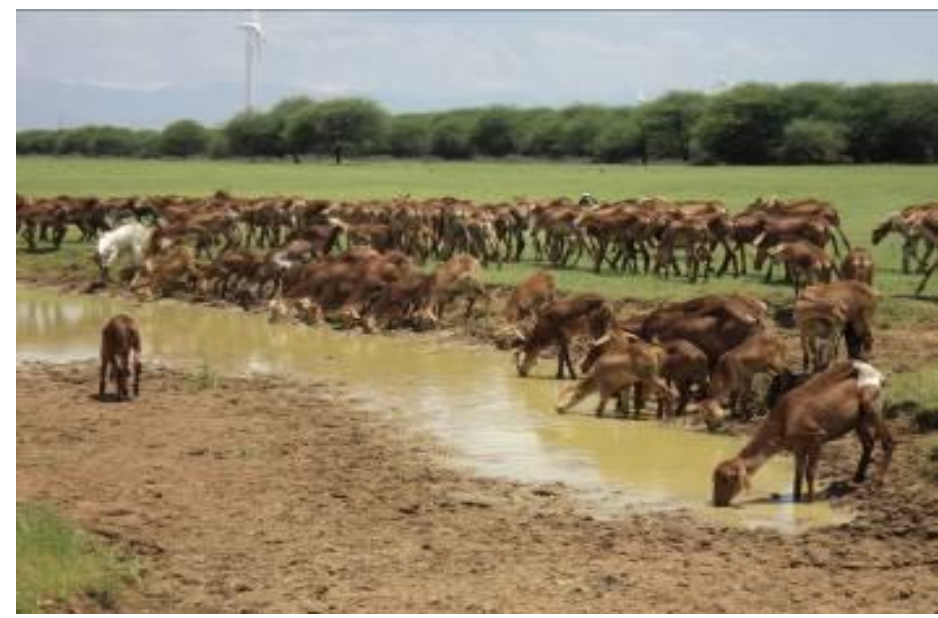

Fig.3 Arichevaadu

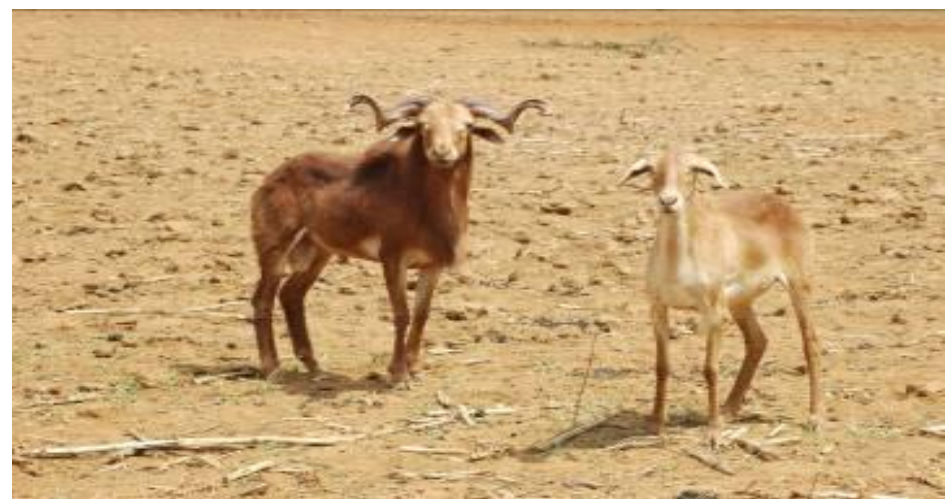

\section{Rearing practices}

Extensive grazing practices are followed by the breeders for Chevaadu sheep in the district. The main sources of grazing are grasses, herbs, stubbles and weeds. Sheep are housed particularly during rainy season; in other seasons the animals are penned in the open field with nylon nets of about four to five feet height supported by iron rods at the corners and throughout the length and breadth.

Figure 1 indicates the special enclosures made for the lambs just after its birth by the Chevaadu farmers, which is locally called as Koodu. Lambs are fed with leaves of Sesbania grandiflora (Agathi) and Azadirachta indica (Neem) for 1 to 3 months before allowed for grazing. Sheep are allowed for watering 2 or 3 times a day based on season and availability. The water source is ponds in general and watering from wells is being practiced during summer months (Fig. 2).

Majority of farmers strive to maintain breed purity and take into consideration breed characteristics (Arichevaadu) while selecting the breeding males (Fig. 3). The flocks with more than 100 ewes observed to have 2 to 3 rams, whereas smaller flocks have only one ram. The farmers use the same rams for more than 2 to 3 years. Exchange of breeding rams between flocks was not uncommon.

Blue tongue, enterotoxaemia, peste des petis ruminants and anthrax are the most prevalent 
diseases. The annual mean mortality rates reported to have six per cent and two per cent respectively for lambs and adults. Coccidiosis and liver flukes are the major causes of mortality in lambs and adults respectively.

\section{Special management}

Sheep are washed once in a month if water is available in ponds; otherwise, no such practices are followed. Hair clipping is done once in a year, mostly during summer month (May). Majority of farmers in the breeding tract have stationary flocks, however, a few farmers go on temporary migration during April to June sometimes it might be extended up to July. The flocks return back with onset of monsoon showers. During migration the sheep are penned on private fields in lieu of stubble grazing and some return is made to the flock owners in cash or kind. Surplus ram lambs are sold at the age of 2 to 21/2 months for Rs. 2,000 to 2,500/whereas all ewe lambs are retained for replacement. Depending upon the condition of the animal, prices of adult ewes and rams varied from Rs. 4,500 to 5,000/- and Rs. 8,000 to $12,000 /$ - respectively.

\section{Breed registration}

In 2009, Chevaadu was identified as distinct breed by TANUVAS. After completion of detailed research on Chevaadu, application for registration was submitted to the Indian Council of Agricultural Research (ICAR) - National Bureau of Animal Genetic Resources (NBAGR), Karnal during March 2015 to register 'Chevaadu' as a breed. The expert team of ICAR-NBAGR visited Tirunelveli and Thoothukudi districts and inspected the characteristics of Chevaadu. The team interacted with people and gathered information during January 2016 and finally ICAR breed registration committee in its meeting held during June 2016 has approved the registration of "Chevaadu Sheep" as a breed. Accession number of Chevaadu breed is INDIA_SHEEP_1800_CHEVAADU_ 14041. The Chevaadu farmers are happy in contribution made to register the breed. The livestock keepers believe that the breed can get wider recognition and they can raise their issues and constraints in sheep rearing with high voice, in future.

\section{References}

Acharya, R.M., FAO, United Nations, Rome, Italy: 1982

Bhatia, S., and Arora, R. 2005. Biodiversity and conservation of India sheep genetic resources - an overview. Asian-Aust. J. Anim. Sci., 1387-1402.

FAO. Animal Production and Health Paper 1986; 59 (2).

Ganesakale, D., Rathnasabapathy V. Cheiron 1973; 2:146-155p

Kumarasamy, P., et al., Proceedings of National Symposium on Livestock Biodiversity Conservation and Utilization. Karnal, Haryana, India: 2009; $134 \mathrm{p}$.

Ravimurugan, T., and Panneerselvam, S. 2013. Morphological Characteristics of Chevaadu Sheep of Tamil Nadu, India. $J$. Vet. Sci., 2(1):1-3.

Ravimurugan, T., Thiruvenkadan, A.K., Krovvidi Sudhakar and Panneerselvam, S. 2012. Sheep Genetic resources of southern Tamil Nadu, India. International Res. J. Agri. Sci. and Soil Sci., 2: 81-88.

Snedecor, G.W., and Cochran, W.G. 1989. Statistical Methods. ( $8^{\text {th }}$ Edn.) Iowa state University Press, Ames, Lowa. Pp. $\mathrm{xx}+503$.

\section{How to cite this article:}

Ravimurugan, T. 2017. Chevaadu - A New Registered Sheep Breed of Tamil Nadu, India. Int.J.Curr.Microbiol.App.Sci. 6(9): 1553-1557. doi: https://doi.org/10.20546/ijcmas.2017.609.190 